\title{
A REVIEW OF THE DISTINGUISHING FEATURES OF THE HISTORICAL BUILDINGS IN SAFRANBOLU REGION FOR THE PURPOSE OF CLASSIFICATION FOR SEMANTICALLY ENHANCED 3D BUILDING MODEL
}

\author{
M. $A k \sin ^{1}$, İ. R. Karaş ${ }^{2, a}$ \\ ${ }^{1}$ Karabuk University, Department of Computer Engineering, Karabuk, Turkey - mustafaaksin@karabuk.edu.tr \\ ${ }^{1}$ Karabuk University, Department of Computer Engineering, Karabuk, Turkey - ismail.karas@ karabuk.edu.tr \\ a Commission IV, WG IV/1
}

KEY WORDS: BIM, HBIM, Building, Historical, Safranbolu, Classification.

\begin{abstract}
:
In addition to making our daily life easier with the use of it in different areas of our lives, technology continues to be used increasingly with different applications in many sectors.

With the increase of developments in the construction sector, which is the locomotive of many sectors, different applications have been used in the field of modelling. But a building needs many projects such as static, dynamic, electricity, installation, furniture, etc. While these sectors are working with different software specific to them, it has been possible to work on these building projects in a single project by the help of BIM (Building Information Modelling).
\end{abstract}

In addition to its function of projecting new buildings, BIM is an important development and building model in terms of preserving historical buildings, easily creating original building details, and transferring them to future generations without deterioration. The term HBIM (Historic / Heritage Building Information Modelling) has been brought to the literature by using the BIM model in historical buildings.

The known history of Safranbolu district of Karabük in Turkey dates back to 3000 years. Safranbolu, which has hosted Roman, Byzantine, Seljuk and Ottoman empires in its history, has buildings that are still preserved with their originality. These structures were built in the pre-Ottoman, the Ottoman and the Republic periods.

In our study, historical buildings such as houses, commercial houses, places of worship, inns, baths, fountains, and clock towers will be examined. Building models and distinctive features were examined to classify these structures by modeling them with BIM. While the differentiation of the buildings can be made easily by the building model, the distinguishing features of the houses built in different periods or by different civilizations were also determined in order to distinguish the housing types.

While structures such as baths, clock towers or inns are not in a number that can be classified, it has been observed that there are residences, businesses and places of worship that can be classified. It has been determined that it is possible to classify the buildings by their materials, building sizes and shapes, and by their other features that can be used to classify.

\section{3D MODELS}

\subsection{BIM (Building Information Modelling)}

Construction, by its nature, is a common activity area of many sectors. BIM (Building Information Modeling) can be defined in many different ways due to its comprehensive, complex and multidisciplinary nature.

BIM is a process that starts with creating an intelligent threedimensional (3D) design model and then uses that model to facilitate coordination, simulation, and visualization while helping business owners and service providers improve the planning, design, construction, and management of buildings and infrastructure. (Autodesk. net., 2014, S. Date: 05.06.2018).

BIM is a technology where a construction project can be projected with many parameters on a single model, the plan, cross-section view and perspectives of the 3D model can be output from anywhere, and the changes made in the model can be transferred to all outputs instantly. (Atabay, vd. 2019)

In summary, BIM can be said to be the process of creating a digital structure model, which includes the interactive management, analysis and improvement of different processes in a common platform.

\subsection{BIM Levels}

BIM has different usage areas in project processes. BIM can accommodate many disciplines according to the level of detail, can be managed at the same time, and their levels are specified as follows:
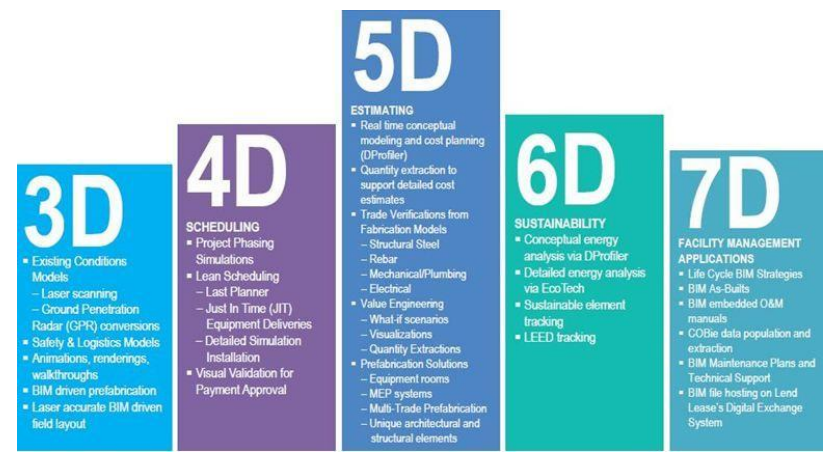

Figure 1. BIM levels. 


\subsection{HBIM (Historical/Heritage BIM)}

The first and most important step of the studies related to the protection of cultural heritage is the complex process that includes the stages of documentation, data collection, interpretation, and production. A brief definition of this is to record the current state of the building and its surroundings with reports, drawings, and photographs. (Y1lmaz et al., 2007).

The HBIM methodology makes this process go faster. At the same time, it makes it easier for different stakeholders in the project to access the information they need, as it allows flexible working.

The working methodology of HBIM is as follows: First, data from laser scanning and photogrammetry is collected and processed. Then, historical details about the building are scanned from the sources and historical parametric objects are designed. As a result of all these studies, project production takes place. As it can be understood from the working methodology, it is possible to produce projects containing threedimensional models, details, plans and sections through HBIM. (Murphy et al., 2013).

New information can be added or quickly edited to the project and objects via shared parameters and project parameters. It is important to use these parameters in BIM in terms of historical building in order to consolidate information that is otherwise difficult to combine and facilitate business networking. (Pauwels \& Bod, 2013).

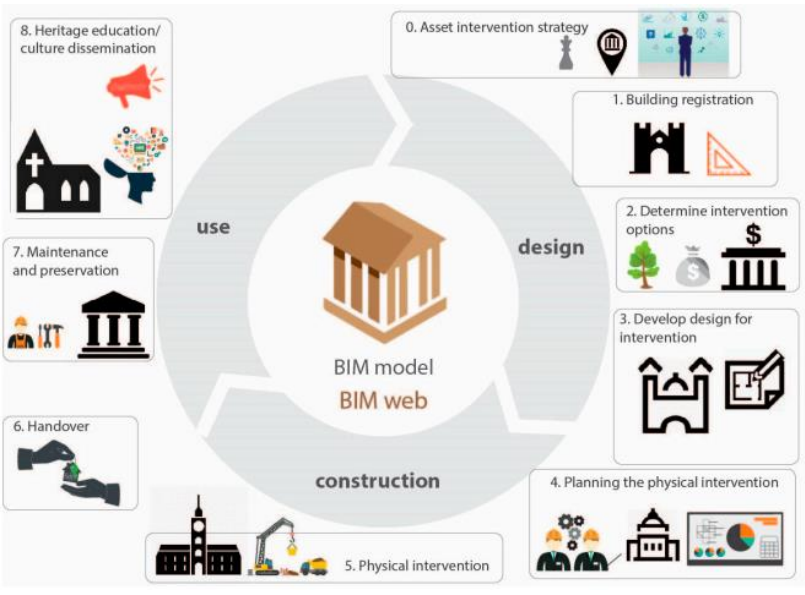

Figure 2. HBIM Overview (Pauwels \& Bod, 2013).

As cultural heritage conservation efforts require interdisciplinary work, many experts and stakeholders meet at a common point. Thus, sharing information between individuals and institutions involved in heritage studies gains importance. Gathering all the information obtained in a single working environment and facilitating access to this information is an important factor for the protection and sustainability of heritage sites. (Kömürcü Esranur vd. 2021)

\section{WORLD HERITAGE CITY SAFRANBOLU}

\subsection{About Safranbolu}

It is known that Safranbolu was called Dadybra when it was under Byzantine rule. The region, in which Safranbolu is located, passed under the rule of Danişmentoğulları in 1100 and met Turkish Culture for the first time in its history. Safranbolu came under the rule of Çobanoğulları in the 13th century and Candaroğulları in the 14th century. As a result of the war between the Ottoman Empire and the Candarogullari in 1392, the region passed to the Ottoman Empire.

In the period of kneading the city with Ottoman culture, its name was Zalifre. Afterwards, it was named Borlu, Taraklıborlu, Zağfiran-1 Bolu in the 18th century, Zağfiranbolu in the 19th century, and Safranbolu in the Republican period. The city was taken into the status of a district of Zonguldak province in 1927 and of Karabük province in 1955.

Since Safranbolu has hosted various cultures, it has a very rooted and historical past mixed with different cultures.

\subsection{Safranbolu Houses}

Houses in Safranbolu, Kastamonu, Sinop and Amasya are grouped as North Anatolian houses. House plans preserved open sofas until a late period (18th century). Its later development was shaped in the direction of the inner and middle sofa. The main carrier system of the houses is mostly filled with adobe and rarely with small stones between the wooden frames on the stone.

The ground floors of the houses are made of stone and form the basis for the upper floors in accordance with the topography. The upper floors are timber-framed. If there is, the middle floor has low ceilings and few windows. On the upper floor, there are many windows and it is animated with overhangs.

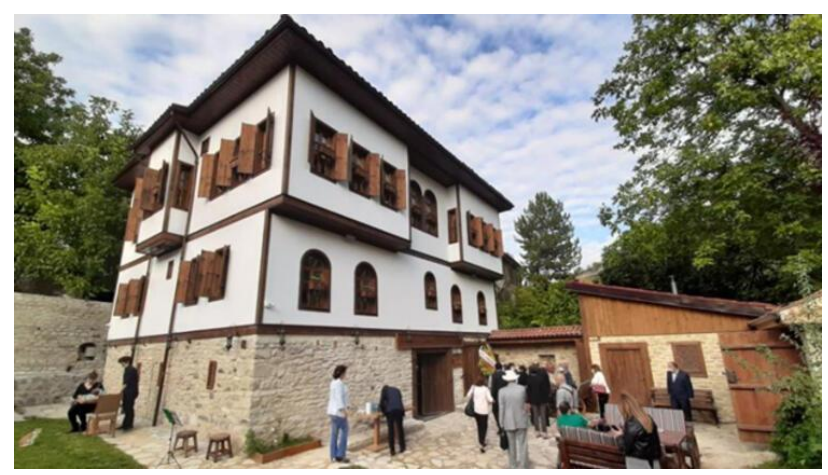

Figure 3. A Safranbolu house.

There are nearly 2000 traditional houses and mansions in the historical city of Safranbolu. Among the 67 Safranbolu houses whose inscriptions have survived to the present day, the earliest building belongs to 1786 and the latest one to 1929 . Houses are usually 2 floors above ground.

\section{SAFRANBOLU HOUSES}

Safranbolu's first development plan was designed in 1936. Putting an emphasis on necessity of preserving the historical texture in the zoning plan by holding a competition created a positive atmosphere. Especially the inclusion of Safranbolu in the UNESCO World Cultural Heritage List in 1994 has created a new process for the city. As a result of this decision, the historical city of Safranbolu, which was a settlement during the Ottoman Empire and is now called the Old Bazaar, was taken into the scope of protection. 
The creation of the HBIM model of the Safranbolu houses under protection will ensure that these protected structures are transferred to future generations with digital copies. In our research, the diversity and differences of the protected structures in Safranbolu in terms of HBIM models are discussed. It has been tried to classify the protected structures in terms of diversity and to indicate the structural differences of the varieties within themselves.

\subsection{Building Variety}

\subsubsection{According to Usage}

When we look at the historical buildings in Safranbolu, it is seen that the buildings vary. These types can be counted as residences, businesses, inns, Turkish baths, fountains, mosques and clock towers. Structures with a large number of examples should be taken into consideration in order to be able to classify. Otherwise, not a class but a special structure will be defined. For this reason, structures with a small number such as fountains, inns, baths and clock towers are excluded from the evaluation, and buildings with sufficient number can be classified as;

- Homes,

- Businesses

- $\quad$ Places of worship

Since the houses show structural differences, they can also be classified differently in terms of structure. Commercial houses, on the other hand, have very different types which are irrelative to each other, such as 4-5 $\mathrm{m} 2$ shops in the Old Bazaar area, Greek type shops located on the lower floor of the houses, and reinforced concrete ones in the Kiranköy area. Although almost all of the buildings that we can call as places of worship are mosques of different qualities, the Greek Church (Hagios Stephanos Church) was converted into a mosque (Ulu Mosque) after the Greeks living in Kiranköy left the city with the Exchange Treaty. For this reason, it was preferred to call it a place of worship rather than a mosque as a general class.

\subsubsection{According to Construction Technique}

When the houses with traditional architecture called Traditional Safranbolu Houses are examined in terms of structure, it is seen that the foundations (ground floor) of the buildings consist of stone walls. A wooden skeleton is built on the stone floor and classification is made with the structure of the walls used in this skeleton.

Wooden framed walls; These are the systems in which the structural loads are transferred to the floor by means of wooden posts and beams within the wall.

These walls were found to adopt four different systems, in terms of 'Pillar Spacing' and 'Filling Material'.

\subsubsection{Adobe Filled Walls}

It is the system with the highest sewing spacing. There is a uniformity in terms of both gap and cross-section dimensions in the pillars on the corners and window edges. The average crosssectional dimensions of the uprights with a spacing of $70-75 \mathrm{~cm}$ are $15 \times 11.7 \mathrm{~cm}$.
Fill adobe (yegdane adobe) whose raw material is earth-straw was used both horizontally and vertically according to the space.

While the mud-brick filled walls plastered from inside and outside constitute $54 \%$ of the houses within the scope of the study, the samples with $70-75 \mathrm{~cm}$ upright spacing are $25 \%$.

\subsubsection{Wood filled walls}

Wood was used as a filling element between the carrier pillars. Infill wood is the re-evaluation of the frame elements of destroyed structures. This building material, which was obtained from old buildings, was placed between the frames in the most appropriate way horizontally and vertically without any system.

Wood filled structures, examples of which were found in the Bağlar region, are very few within the scope of the field study.

Among the wood-filled samples, only two examples were encountered. The rate of this is $4 \%$.

\subsubsection{Stone filled walls}

In stone filled walls, the number of vertical carriers has been increased, and the spacing of the pillars varies between $20-25$ $\mathrm{cm}$, regardless of main or secondary. It was mostly used in houses in Bağlar region.

\subsubsection{Stone-Adobe filled walls}

The carrier pillars have been divided by considering the corners, door-window edges and the junctions of the intersecting walls. Secondary struts are placed according to the material to be filled.

There are two separate systems.

- Samples with a sewing spacing of 30-35 cm

- Samples with a sewing spacing of $40-45 \mathrm{~cm}$

\section{CONCLUSION}

As a result of the examinations, it has been seen that when the building diversity is considered, it can be examined in three main classes as residence, commercial place and place of worship.

As a result of the structural analysis; It has been observed that $94 \%$ of the stones are used on the ground floor walls, and the classification can be made according to the living floor walls. Living floor walls, on the other hand, can be classified according to the type of filling and their structure may vary accordingly. Living floor walls are wooden framed walls filled with wood, adobe and stone, except for the back wall of a few examples.

As a result of the creation of the BIM model of the structures, the classification of the structures as diversity and this classification can be automated. For the houses, it is possible to easily make a classification with the above-mentioned structural differences. 


\section{REFERENCES}

Atabay, Ş., Öztürk, M.B., (2019). Yapı Bilgi Modellemesi (YBM) Uygulama Planı Üzerine İnceleme, Mühendislik Bilimleri ve Tasarım Dergisi, 7(2), 418-430.)

Autodesk. net., 2014. YBM Pilot Projesi Başlangıç Rehberi. https://forums.autodesk.com, (Access date: 05.06.2018)

B. Oral; "Cumhuriyet Dönemi Safranbolu Cami Mimarisi ve Etkileşim Unsurları"; Sosyal, Beşerî ve İdari Bilimler- 3 Alanında Yeni Ufuklar (pp.31-65), Gece Kitaplığ $1,2019$.

B. Oral, "Geleneksel Mimariye Öykünme Bağlamında Günümüz Safranbolu Sivil Mimarisi", İnsan ve İnsan, c. 6, say1. 21, ss. 597-631, Ağu. 2019, doi:10.29224/insanveinsan.526182

Kömürcü E., Benli Yıldız N., 4th International Conference of Contemporary Affairs in Architecture and Urbanism (ICCAUA2021) 20-21 May 2021.

Murphy, M., McGovern, E., \& Pavia, S. (2013). Historic Building Information Modelling - Adding intelligence to laser and image based surveys of European classical architecture. ISPRS Journal of Photogrammetry and Remote Sensing, 76, 89-102. https://doi.org/10.1016/j.isprsjprs.2012.11.006.

Oreni D. (2013) From 3D Content Models to HBIM for Conservation and Management of Built Heritage. In: Murgante B. et al. (eds) Computational Science and Its Applications ICCSA 2013. ICCSA 2013. Lecture Notes in Computer Science, vol 7974. Springer, Berlin, Heidelberg. https://doi.org/10.1007/978-3-642-39649-6_25

P. Pauwels, R. Bod, D. D. M. and R. D. M. (2013). "Integrating building information modelling and semantic web technologies for the management of built heritage information," 2013 Digital Heritage International Congress (DigitalHeritage), Marseille, 2013,. Içinde Integrating building information modelling and semantic web technologies for the management of built heritage information.

https://doi.org/10.1109/DigitalHeritage.2013.6743787.

R. Yetiş Et Al., "Safranbolu Kent Formunun Tarihsel Serüveni ve Morfolojik İncelemesi," II. Kentsel Morfoloji Sempozyumu, İstanbul, Turkey, 2018.

S. Aktüre, T. Şenyapılı; "Safranbolu'da Mekânsal Yapının Gösterdiği Nitelikler ve Koruma Önerilerinin Düşündürdükleri”. O.D.T.Ü. Mimarlık Fakültesi Dergisi, 2(1), s. $61-96,1976$.

Yilmaz, H. M., Yakar, M., Gulec, S. A., \& Dulgerler, O. N. (2007). Importance of digital close-range photogrammetry in documentation of cultural heritage. Journal of Cultural Heritage, 8(4), 428-433. https://doi.org/10.1016/j.culher.2007.07.004. 